\title{
Hsp90 is a viable therapeutic target in the treatment of KSHV-associated primary effusion lymphoma
}

\author{
Utthara Nayar ${ }^{1 *}$, Pin Lu', Jelena Vider ${ }^{2}$, Leandro Cerchietti ${ }^{3}$, Gabriela Chiosis ${ }^{4}$, Lynn Wang ${ }^{1}$, Ronald Blasberg ${ }^{2,5}$ \\ Ethel Cesarman ${ }^{1}$ \\ From $12^{\text {th }}$ International Conference on Malignancies in AIDS and Other Acquired Immunodeficiencies \\ (ICMAOI) \\ Bethesda, MD, USA. 26-27 April, 2010
}

\section{Background}

Hsp90 is a chaperone protein that binds client proteins involved in the regulation of cell survival and apoptosis signal transduction, including Akt, IKK complex, Apaf1 , survivin, CDKs, and KSHV vFLIP. This binding is necessary to maintain proper protein folding, assembly, transport, and function. A lack of Hsp90 results in protein misfolding, ubiquitination, and degradation. KSHV vFLIP was identified as a viral gene that is responsible for NF- $\kappa \mathrm{B}$-dependent anti-apoptotic gene expression in primary effusion lymphoma (PEL) cells [1]. In particular, the IKK signaling complex consisting of IKK $\alpha$, IKK $\beta$, IKK $\gamma$, vFLIP, and Hsp90 in the case of PEL cells was demonstrated as essential for survival in these cells. As Hsp90 forms part of the IKK signalosome in PEL cells, the Hsp90 inhibitor geldanamycin was previously tested in these cells and has been shown to inhibit activity of this complex in vitro. However, geldanamycin is of limited therapeutic potential due to its undesirable pharmacophysiology. We tested a new purine-scaffold Hsp90 inhibitor with high selectivity for tumor versus normal cell Hsp90, which is water-soluble with high oral bioavailability and excellent therapeutic window $[2,3]$.

\section{Materials and methods}

We evaluated the sensitivity of several KSHV infected and uninfected cell lines to treatment with this inhibitor, called PU-H71. We performed viability and NF- $\kappa \mathrm{B}$

\footnotetext{
*Correspondence: utn2001@med.cornell.edu

'Department of Pathology and Laboratory Medicine, Weill Cornell Medical College, New York, NY, USA

Full list of author information is available at the end of the article
}

reporter luciferase assays. Immunoblot analyses to cellular and viral proteins were done to assess the effect of PU-H71. Finally, we used a mouse PEL xenograft model and in vivo imaging to assess tumor responses to PU-H71.

\section{Results}

We found all KSHV-positive PEL cell lines to be exquisitely sensitive when compared to uninfected lymphoma cells, with growth inhibition at $\mathrm{IC}_{50} \mathrm{~s}$ in the nanomolar range. PU-H71 was shown to induce PEL cell death by apoptosis and autophagy within 48 hours of treatment. Western blot analysis indicated that the IKK signaling complex components vFLIP and IKK $\gamma$ were degraded upon PU-H71 treatment, leading to destabilization of the complex, and inhibition of NF- $\kappa \mathrm{B}$ signaling, as confirmed by reporter luciferase assay. PU-H71 was further tested in a mouse xenograft model of PEL and shown to inhibit progression of tumor spread and confer a significant survival advantage $(\mathrm{p}<0.02)$ in these mice.

\section{Conclusions}

Our findings suggest that Hsp90 inhibition with PU-H71 is a promising targeted approach for the treatment of PEL and warrants further preclinical and clinical investigation.

\section{Acknowledgements}

This article has been published as part of Infectious Agents and Cancer Volume 5 Supplement 1, 2010: Proceedings of the $12^{\text {th }}$ International Conference on Malignancies in AIDS and Other Acquired Immunodeficiencies (ICMAOI). The full contents of the supplement are available online at http://www.biomedcentral.com/1750-9378/5?issue=S1. 


\section{Author details}

'Department of Pathology and Laboratory Medicine, Weill Cornell Medical College, New York, NY, USA. ${ }^{2}$ Department of Neurology, Memorial SloanKettering Cancer Center, New York, NY, USA. ${ }^{3}$ Department of Medicine, Weill Cornell Medical College, New York, NY, USA. ${ }^{4}$ Department of Molecular Pharmacology and Chemistry, Memorial Sloan-Kettering Cancer Center, New York, NY, USA. ${ }^{5}$ Department of Radiology, Memorial Sloan-Kettering Cancer

Center, New York, NY, USA.

Published: 11 October 2010

\section{References}

1. Guasparri I, Keller SA, Cesarman E: KSHV vFLIP is essential for the survival of infected lymphoma cells. J Exp Med 2004, 199(7):993-1003, Erratum in: J Exp Med 2006 May 15;203(5):1383.

2. Immormino RM, Kang Y, Chiosis G, Gewirth DT: Structural and quantum chemical studies of 8-aryl-sulfanyl adenine class Hsp90 inhibitors. J Med Chem 2006, 49(16):4953-4960.

3. Cerchietti LC, Lopes EC, Yang SN, Hatzi K, Bunting KL, Tsikitas LA, Mallik A, Robles Al, Walling J, Varticovski L, Shaknovich R, Bhalla KN, Chiosis G, Melnick A: A purine scaffold Hsp90 inhibitor destabilizes BCL-6 and had specific antitumor activity in BCL-6-dependent B cell lymphomas. Nat Med 2009, , 12: 1369-1376.

doi:10.1186/1750-9378-5-S1-A36

Cite this article as: Nayar et al:: $\mathrm{Hsp} 90$ is a viable therapeutic target in the treatment of KSHV-associated primary effusion lymphoma. Infectious Agents and Cancer 2010 5(Suppl 1):A36.

\section{Submit your next manuscript to BioMed Central and take full advantage of:}

- Convenient online submission

- Thorough peer review

- No space constraints or color figure charges

- Immediate publication on acceptance

- Inclusion in PubMed, CAS, Scopus and Google Scholar

- Research which is freely available for redistribution

Submit your manuscript at www.biomedcentral.com/submit 